Winter 2013

\title{
Popular Discontent, Revolution, and Democratization in Egypt in a Globalizing World
}

Abdel-Fattah Mady

Alexandria University, Egypt, Abdelfattah.Mady@gmail.com

Follow this and additional works at: https://www.repository.law.indiana.edu/ijgls

Part of the Comparative and Foreign Law Commons, and the International Law Commons

\section{Recommended Citation}

Mady, Abdel-Fattah (2013) "Popular Discontent, Revolution, and Democratization in Egypt in a Globalizing World," Indiana Journal of Global Legal Studies: Vol. 20 : Iss. 1 , Article 11.

Available at: https://www.repository.law.indiana.edu/ijgls/vol20/iss1/11

This Symposium is brought to you for free and open access by the Law School Journals at Digital Repository @ Maurer Law. It has been accepted for inclusion in Indiana Journal of Global Legal Studies by an authorized editor of Digital Repository @ Maurer Law. For more information, please contact rvaughan@indiana.edu.

\section{$\Psi$}

JEROME HALL LAW LIBRARY

INDIANA UNIVERSITY

Maurer School of Law
Blooming ton 


\title{
Popular Discontent, Revolution, and Democratization in Egypt in a Globalizing World
}

\begin{abstract}
ABDEL-FATTAH MADY*
ABSTRACT

This paper examines how informal, discontent actors in Egypt have evolved in a globalizing world and their role in the January 25th revolution. It focuses on the effects of the deteriorating economic and social conditions in Egypt related to the former regime's policy and the role of mass media, information, and communication technologies in facilitating mobilization, recruitment, and eventually the popular uprising. This paper also discusses the issue of how informal discontent protesters and groups formulate their goals and organize themselves to exert pressure on formal institutions of the state. The main conclusion is that informal actors have not yet managed to develop a shared political agenda with a focus on democratic transition in Egypt and have instead regressed to their own goals and agendas. In light of current political polarization, this paper concludes that there is a need to form a historical block on the basis of democracy or a national-unity government to be able to set priorities and build the desired democratic system.
\end{abstract}

\section{INTRODUCTION}

Successful regime transitions in Eastern Europe, Asia, Latin America, and Africa have often depended on three factors, and the presence of at least one of the three has been essential. First, a group of reformers with a true desire for change within the regime. Second, a democratic opposition capable of using the limited freedoms granted by authoritarian leaders to either compel the ruling elites to release their control over the regime or to negotiate a peaceful transition to

* Abdel-Fattah Mady is Associate Professor of Political Science at Alexandria University, Egypt. He can be reached at the following addresses: Abdelfattah.Mady @gmail.com or www.abdelfattahmady.net

Indiana Journal of Global Legal Studies Vol. 20, Issue 1 (2013)

(C) Indiana University Maurer School of Law 
democracy (such a group is known as a "Pact" in the literature of comparative politics). Third, an end to external support for authoritarian regimes-or, if previously present, the end of external obstruction of democratization. All three factors have proved integral. ${ }^{1}$

Yet, there is a fourth factor: a change from below. Where no divisions within the ruling elite have emerged or where no democratic opposition has organized, political regimes have collapsed either under the pressure of mass demonstrations or at the hands of military personnel who once supported the regime, or by both factors together (examples include Romania, Portugal, Zaire, Iran, Haiti, and Mauritania). External powers have been unable or unwilling to save existing political regimes in the described circumstances. In some cases related to this fourth factor, countries such as Romania, Portugal, and perhaps Mauritania have moved to democracy, but the most common scenario has been a move to a new form of authoritarianism (Castro in Cuba, Khomeini in Iran, and Kabila in the Democratic Republic of Congo). ${ }^{2}$

In the Arab countries, the absence of reformers within the ruling elites and the weakness and fragmentation of the opposition have led to the fourth transition factor, namely a regime collapse under the pressure of mass demonstrations. ${ }^{3}$ The January 25 th revolution in Egypt demanded the overthrow of the regime of President Hosni Mubarak. It focused on a set of political and socioeconomic issues, including emergency laws, police brutality, a lack of democratic

1. See Samuel P. Huntington, The ThiRd Wave: Democratization in the Late TWENTIETH CENTURY 37-38 (1991); GEORGE SØRENSEN, DEMOCRACY AND Democratization: Process and Prospects in a Changing World 13-15 (3rd ed. 2008);

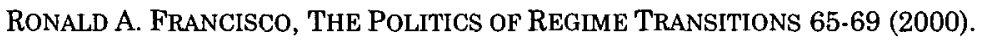

2. See generally Richard Snyder, Paths out of Sultanistic Regimes: Combining Structural and Voluntarist Perspectives, in SUltanistic Regimes 59 (H.E. Chehabi \& Juan J. Linz eds., 1998) (examining Iran and Cuba, among other countries); Richard Snyder, Explaining Transitions from Neopatrimonial Dictatorships, 24 CoMP. PoL. 379 (1992) (studying the Philippines, Haiti, Paraguay, and Zaire as nonrevolutionary cases of transitions).

3. See generally Stiftung Wissenschaft und Politik German Institute for International and Security AfFairs, Protest, Revolt and Regime Change in the ARab World: ACtors, Challenges, Implications and Policy Options, (Muriel Asseburg ed., Meredith Dale trans., 2012), available at: http://www.swp-berlin.org/en/ publications/swp-research-papers/swp-research-paper-detail/article/arab_world_revolt_ and_regime_change.html (collecting together various articles on the changes happening in the recent Arab world); Center for Social Justice, The ARAB Revolts Against NEOLIBERALISM (2011), available at http://www.socialistproject.ca/documents/ArabRevolts .pdf (collecting together essays on how in 2011 the Arab world, focusing on Egypt, underwent transition); Abdel-Fattah Mady, Regime Transition Approaches, in ARAB TRANSITION TO DEMOCRACY: A COMPARATIVE ANALYSIS (Ali AlKuwari \& Abdel-fattah Mady eds., 2009). 
elections and freedoms, corruption, low minimum wages, inflation, and unemployment. Most revolutionary slogans concerned freedom, dignity, and social justice.

The core of this article examines the role of popular discontent groups in the January 25th revolution in Egypt. The article focuses on several main questions: How have popular, informal discontent actors in Egypt evolved in globalizing world? What is their role in the January 25th revolution? Finally, how does globalization affect Egypt's move toward a democratic political system? This article also examines the effects of globalization on democratization first by looking at the deteriorating political, economic, and social conditions in Egypt due to the regime's policies and whether these policies resulted from globalization and world economic integration. The article then analyzes the role of mass media and information and communication technologies (ICT) - especially the Internet and satellite news stationsin facilitating mobilization, recruitment, and eventually the process of democratization.

To answer the questions posed, the article first examines the structural explanations for the dominance of informal politics in Egypt vis-à-vis "legitimate" or formal opposition parties, official unions, and formal professional syndicates. The article also analyzes informal networks, values, and discourses of youth protest groups and social movements as well as the effects of state economic and social policies. Futhermore, the article treats the issue of how informal protesters and groups formulate their goals and organize themselves to exert pressure on formal state institutions. The article continues on to explore the possible social and political effects of ICT, i.e. the ways and means by which ICT tools appear to be empowering political actors and eventually promoting democratization.

Finally, the article addresses the impact of informal political actors on formal political processes in Egypt. The discussion considers the behavior of popular youth protesters and groups toward state institutions and the interactions of informal and formal actors. The main aim here is to investigate whether those informal actors managed to develop a political agenda focused on democratic change in Egypt or if they regressed to prioritizing their own goals and agendas.

\section{MUBARAK'S POLITICAL LEGACY}

In authoritarian regimes, structural impediments have prevented the emergence of democratic opposition and the evolution of political openness into a real democratic transition. These impediments have become more important as a result of the nature of relationships 
between ruling elites and state institutions, society, and foreign patrons. Egypt, like many other third-world countries, suffered from such structural impediments as well as from other impediments peculiar to Egypt, most of which have perhaps originated from the authoritarian systems where it is hard to distinguish between the ruler, the political regime, and the "state."4

Mubarak's regime had succeeded in taking advantage of structural impediments-including the ruling elite's control over the state and society-with a self-serving strategy to survive and maintain the status quo. ${ }^{5}$ Indeed, the ruling elite's monopoly on power constituted one of the main obstacles to democratization. Specifically, Mubarak and his close circle exercised control over society through various means such as oppression, intimidation, and emergency laws. ${ }^{6}$ The regime also created divisions within any group that did not express its loyalty to the ruling elite and its allies. Larry Diamond properly notes, "the principle obstacle to the expansion of democracy in the world is [not] the people of these authoritarian states. The problem is the ruling elites who have hijacked the structures of state power and barricaded themselves inside."?

For decades, Mubarak learned numerous lessons from his authoritarian counterparts; the most significant was that absolute rule requires allowing a degree of freedom of expression and political openness, given that traditional sources of legitimacy have faded away. Such a strategy prevented an explosion (as in Romania) or a collapse (as in the Soviet Union). Political openness, however, required an accompanying ability to crush the opposition and to control society through all available means. Those means were topped by soft power tools, such as less aggressive methods, including "the divide and rule strategy," "buying the elite's loyalty," and enacting laws that tighten the government's grip over society and political parties. ${ }^{8}$ The point of all this was to avoid weakening the ruling elite and to prevent the emergence of

4. See H.E. Chehabi \& Juan J. Linz, A Theory of Sultanism 1: A Type of Nondemocratic Rule, in SULTANISTIC REgImES 3, 11 (H.E. Chehabi \& Juan J. Linz eds., 1998) (discussing "the blurring of the line between the regime and the state").

5. For more detail, see AL KUWARI (علي الكراري), DESPOTISM IN CONTEMPORARY ARAB REGIMES (الاستبداد في نظم الحكم العربية المعاصرة) (2005) (Leb.) (discussing authoritarian regimes manipulating citizens).

6. ABDEL-FatTaH Mady, Islam and DEMocracy: Elite Political ATTITUdes and THE DEMocratization PROCESS IN THE ARAB REgION 51 (2005).

7. Larry Diamond, Can the Whole World Become Democratic? Democracy, Development, and International Policies 21 (Apr. 17, 2003) (on file with the Center for the Study of Democracy), available at http://escholarship.org/uc/item/7bv4b2w1.

8. MADY, supra note 6 (examining political attitudes in the Arab region towards democratization). 
a democratic opposition, thus impeding a recurrence of the Polish, the Philippine, or the Mexican democratization experiences. Further, Mubarak had learned not to trust the outcome of truly democratic elections in order to avoid going through an experience similar to that of Hungary or Chile.

Moreover, if Mexico-where the technocrats were in power and participated in their county's democratic transition-is compared to Egypt, ${ }^{9}$ it becomes evident that the ruling party in Egypt had succeeded at keeping a tight grip over both the old guard and those known as the new generation (the so-called Future trend within the ruling party, led by the President's son and a group of businessmen). ${ }^{10}$ The party had also attracted independent politicians who won parliamentary seats without being nominated by the ruling party. ${ }^{11}$

Among the factors that helped the ruling elites maintain their control over society and hinder democratic transition was the sectarian issue between Muslims and Copts. The ruling party utilized fear of sectarian unrest to justify its attempts to maintain the status quo. ${ }^{12}$

In addition, for decades public pressure remained mild in Egypt. The demonstrations that took place were usually motivated by economic or regional rather than political causes. ${ }^{13}$ Although new forms of political activism, such as the Kifaya movement or blogging, had become part of the political scene, they had failed to attract more than a few hundred supporters in a country of eighty million people in 2007.14 These activities had not led to the emergence of a moderate leadership, and the political discourse could not rally diverse political forces. In 2011 , the youth and protest movements managed to mobilize huge numbers of people by using social networks. As discussed below, social networks have enabled mobilization of the people and execution of

9. See generally Diane Singerman, The Politics of Emergency Rule in Egypt, 101 CURRENT HIST. 29 (2002) (explaining Egypt's government's use of military law, political regulation, and military law as a basis to retain state control).

10. See generally, MADY, supra note 6, at 64-65.

11. Abdelgafar Shokr, Independents in Elections, in 2010 PEOPLE'S CoUNCIL ELECTIONS 87-88 (Amr Hashim Rabie ed., 2011).

12. This conception is common in the Arab countries. For example, in April 2008, the media reported a statement by the Yemeni President Ali Abdullah Saleh that the conflict with Houthis in the south was hindering his adoption of his election program. See, e.g., Jane Novak, State of Emergency in Yemen, ARMIES OF LIBERATION (Apr. 22, 2008, 6:28 PM), http://armiesofliberation.com/archives/2008/04/22/state-of-emergency-in-yemen/.

13. Rabab El-Mahdi, Enough!: Egypt's Quest for Democracy, 42 CoMP. PoL. STUD. 1011, 1013 (2009).

14. Id. at 1018 . 
political action, and have become an important obstacle for the survival of the authoritarian system. ${ }^{15}$

Formal opposition parties in Egypt certainly did not play the typical role of opposition in democracies, which is to say they did not necessarily represent different social groups or compete for power. They did not even undertake the role of opposition groups that seek true political transition. On the contrary, the Egyptian opposition parties helped the regime in acquiring legitimacy, contained the true opposition, and sabotaged any attempt at creating democratic alliances. Some of these parties ran to appease the regime who rewarded them with benefits and offices. 16

On the other hand, due to the confusion between "the state," "the political regime," and "the government," the ruling elites portrayed the opposition groups as threats to the regime and national security. Such arguments justified giving more power to security apparatuses and to the army. Similar justifications were also used for curbing rights and freedoms as well as for militarizing the entire country. ${ }^{17}$

In Egypt, the country in which the Muslim Brotherhood (MB) and many other Islamist groups were born, Islamists had been deprived of their right to participate in political life through official parties or organizations since $1954 .{ }^{18}$ The regime regarded all Islamist groups as dangerous and sometimes labeled them as terrorists who sought to threaten the status quo and subvert the ruling regime. According to official discourse, the existence of the $\mathrm{MB}$ was the reason to stay away from political reforms. ${ }^{19}$ The official argument was that "truly free elections would lead to the 'Algerian problem,' or to 'one vote, one time,' meaning that a newly elected government would end elections or restrict them to the point of meaninglessness." 20

Egypt has been classified as an authoritarian and nonfree country in most international indexes, as shown in the table below.

15.. Marko Papic \& Sean Noonan, Social Media as a Tool for Protest, STRATFOR (Feb. 3, 2011, 9:54 AM GMT), http://www.stratfor.com/weekly/20110202-social-media-tool-protest\# ixzz22KfBMk00.

16.. For political parties in Egypt, see: WAHEEd ABdelmaged (وحيد عبدالمجيد), THE CRISIS OF DEMOCRACY WITHIN EGYPTIAN POLITICAL PARTIES (ازمة النيمقر اطية فى الاحزاب المصرية) (2008).

17.. See MADY, supra note 6, at 112-13 (discussing how "external factors," such as outside aggression, are used to justify "survival of the regime").

18. MADY, supra note 6 , at 51 .

19.. Id. 108.

20.. Id. 108. 
Table 1: Egypt's international ranks

\begin{tabular}{|c|c|c|}
\hline Index & Rank & Score \\
\hline $\begin{array}{c}\text { Corruption Perceptions } \\
\text { Index (2011) }\end{array}$ & $112 / 183$ & $2.9 / 10$ \\
\hline $\begin{array}{c}\text { Judicial Independence } \\
(2011-2012)^{\mathrm{b}}\end{array}$ & $41 / 142$ & $4.8 / 7$ \\
\hline $\begin{array}{c}\text { Rule Of Law (2011) } \\
\text { (2011) }\end{array}$ & - & -0.42 \\
\hline $\begin{array}{c}\text { Voice \& Accountability } \\
(2012)^{\mathrm{e}}\end{array}$ & - & -1.13 \\
\hline $\begin{array}{c}\text { Press Freedom Index (2011- } \\
2013\end{array}$ & $166 / 179$ & 97.50 \\
\hline $\begin{array}{c}\text { Freedom House (2011) } \\
\end{array}$ & Freedom Rating: & Not Free \\
\hline
\end{tabular}

a. Source: Transparency International, available at http://www

transparency.org/whatwedo/pub/corruption_perceptions_index_2011. Scores range from 0 (highly corrupt) to 10 (very clean).

b. Source: World Economic Forum, Country/Economy Profiles: Egypt, available at http://www3.weforum.org/docs/GCR2011-12/CountryProfiles/Egypt.pdf. Scores range from 1 (heavily influenced) to 7 (entirely independent).

c. Source: World Bank, available at http://info.worldbank.org/governance /wgi/mc_chart.asp. Point estimates range from about -2.5 to 2.5 . Higher values correspond to better governance outcomes.

d. Source: World Bank available at http://info.worldbank.org/governance

/wgi/mc_chart.asp. Point estimates range from about -2.5 to 2.5 . Higher values correspond to better governance outcomes.

e. Source: Worldwide Press Freedom Index 2011/12, available at http:// www.

nationsonline.org/oneworld/press freedom.htm.

f. Source: Freedom House, available at

http://www.freedomhouse.org/report/freedom-world/2011/egypt.

\section{MUBARAK'S ECONOMIC LEGACY}

The role played by economic factors and the repercussions of the economic situation in the choices of elite groups and politicians, and in 
their communication strategies cannot be overlooked. ${ }^{21}$ The economic needs of many social classes ensure balance to this equation: material benefits in return for political loyalty. ${ }^{22}$ Economic need is also the backbone of the ruling elites' dependence on foreign actors. Indeed, the economic crises of the 1970 s and 1980 s affected the economic performance of governments by shrinking growth rates and raising inflation rates. The crises themselves were insufficient to put an end to authoritarianism, but the mismanagement of the economic crises was one of the reasons for the erosion of the legitimacy of authoritarian regimes. ${ }^{23}$

In Egypt, there were many opportunities to exploit and overcome the economic crises due to a variety of factors, most importantly the use of financial means arising from either natural resources or foreign backers. Businessmen and medium-sized business owners were interested in maintaining the status quo as long as their interests were not subject to direct threats, especially in light of the government's tendency to bring major businessmen into its entourage and to grant them political and parliamentary seats. Ruling elites tolerated corruption, bribery, and abuse of authority, thus maintaining the status quo for numerous individuals and communities. ${ }^{24}$ If those communities were ever to shift their loyalty, the cost of oppression would increase, and the position of the ruling elites would become weaker, thus facilitating democratic transition. This may now be taking place in Egypt and other Arab countries. ${ }^{25}$

Economic factors play an influential role in the processes of democratization; in some states political transition requires an economic move toward a free market, as was the case in Eastern European countries in the early 1990s. The Egyptian economic system was free after the implementation of the World Bank reform program in the

21. See Stephan Haggard \& Robert R. Kaufman, The Political Economy of Democratic Transitions, in Transitions To Democracy 72, 77-79 (Lisa Anderson ed., 1999).

22. For more details, see, for example, Kurt Weyland, The Politics of Corruption in Latin America, 9 JouRnal OF DEMOCRACY 108 (1998) (distinguishing corruption from political patronage and discussing corruption generally); ANDRE BANK \& THOMAS Richter, NeOpatrimonialism IN THE MidDle EAST AND NoRTH AFrica: Overview, CRITIQUE AND ALTERNATIVE CONCEPTUALIZATION (2010) (identifying the dependency of the client to the patron).

23. See generally Omololu Fagbadebo, Corruption, Governance and Political Instability in Nigeria, 1 AFR. J. OF POL. SCI. AND INT'L REL. 28 (2007) (examining Nigeria and describing how the poor economy is due, in part, to the authoritarian regime that was in place).

24. See Chatham House, Defining and Tackung CoRruption (2008), available at http://www.chathamhouse.org/publications/papers/view/182782.

25. See MADY, supra note 6. 
1990s. ${ }^{26}$ Yet, the Egyptian economy has suffered from significant imbalances at the macro level and was also negatively affected by high corruption rates and the presence of a group of businessmen in Ahmad Nazif's government in July 2004. ${ }^{27}$

Table 2: Basic economic data in Egypt

\begin{tabular}{|c|c|c|c|c|c|}
\hline Indicator & $\mathbf{1 9 8 1}$ & $\mathbf{1 9 9 1}$ & $\mathbf{2 0 0 1}$ & $\mathbf{2 0 0 5}$ & $\mathbf{2 0 0 6}$ \\
\hline $\begin{array}{c}\text { GDP (PPP) } \\
\text { per capita, } \\
\text { (Current } \\
\text { International } \\
\$ \text { ) }\end{array}$ & $1,406.268$ & $2,654.290$ & $4,051.913$ & $4,762.119$ & $5,156.672$ \\
\hline $\begin{array}{c}\text { GDP per } \\
\text { capita at } \\
\text { constant } \\
\text { prices, (EGP) }\end{array}$ & $3,418.944$ & $4,508.064$ & $5,675.467$ & $6,074.286$ & $6,371.669$ \\
\hline $\begin{array}{c}\text { GDP per } \\
\text { capita at } \\
\text { current } \\
\text { prices, (EGP) }\end{array}$ & 411.195 & $2,121.207$ & $5,544.049$ & $7,692.857$ & $8,663.394$ \\
\hline $\begin{array}{c}\text { GDP per } \\
\text { capita at } \\
\text { current } \\
\text { prices, (US\$) }\end{array}$ & 587.422 & 878.615 & $1,474.481$ & $1,282.766$ & $1,505.957$ \\
\hline
\end{tabular}

Source: IMF WEO Online database, available at http://www.imf.org/external/pubs/ft/weo/2012/01/weodata/weorept.aspx?pr.x=32\&pr.y=7\&s $\mathrm{y}=1981 \&$ ey $=2017 \& \mathrm{sesm}=1 \& \mathrm{ssd}=1 \&$ sort $=$ country\&ds $=. \& \mathrm{br}=1 \& \mathrm{c}=469 \& \mathrm{~s}=\mathrm{NGDP} \mathrm{R} \% 2 \mathrm{CNG}$ DP_RPCH\%2CNGDP\%2CNGDPD\%2CNGDP_D\%2CNGDPRPC\%2CNGDPPC\%2CNGDP

26. This structural adjustments program focused on "conditionalities," i.e. conditions for obtaining new loans from the World Bank or the International Monetary Fund, or for obtaining lower interest rates on existing loans to reduce Egypt's fiscal imbalances. This program, which was supposed to allow Egypt's economy to become more market-oriented, included major changes - basically privatization, the reduction of trade barriers, reduction in government expenditure, and deregulation. See Factsheet, IMF Conditionality, INTERNATIONAL MONETARY FUND (Sept. 26, 2012), http://www.imf.org/external/np/exr /facts/conditio.htm.

27. World Economic Outlook Database, InTERnATIONAL MONETARY Fund, http://www.imf.org/external/pubs/ft/weo/2012/01/weodata/index.aspx (click on "By Countries," select "Middle East and North Africa," select "Egypt," select the appropriate national accounts, then choose the date range from the dropdown box). 
DPC\%2CPPPGDP\%2CPPPPC\%2CPPPSH\%2CPPPEX\%2CNID_NGDP\%2CNGSD_NGDP \%2CPCPI\%2CPCPIPCH\%2CPCPIE\%2CPCPIEPCH\%2CTM_RPCH\%2CTMG_RPCH\%2C TX_RPCH\%2CTXG_RPCH\%2CTXGO\%2CTMGO\%2CLUR\%2CLP\%2CGGR\%2CGGR_NG DP\%2CGGX\%2CGGX_NGDP\%2CGGXCNL\%2CGGXCNL_NGDP\%2CGGSB\%2CGGXON LB\%2CGGXONLB_NGDP\%2CGGXWDN\%2CGGXWDN_NGDP\%2CGGXWDG\%2CGGX WDG_NGDP\%2CNGDP_FY\%2CBCA\%2CBCA_NGDPD\&grp=0\&a= (last visited Mar. 27, 2013).

Indeed, the World Bank program led to increased inflation and economic instability. ${ }^{28}$ As in many other authoritarian regimes, Mubarak's government remained politically stable due to the support of Washington and international financial institutions on one hand, and a façade of both a multi-party system and elections, on the other hand. ${ }^{29}$

Nevertheless, Egypt benefited from the global economic prosperity during the period between 2005-2008, before the recent financial crisis. This prosperity was due to rising oil prices, the Gulf countries' growing investments in Egypt, profits from the Suez Canal, and tourism. ${ }^{30}$ Hence, the growth rate has increased, as shown in the figure below. ${ }^{31}$

28. See generally Stephan Haggard, The Politics of Adjustment: Lessons from the IMF's Extended Fund Facility, 39 INT'L ORG. 505 (1985) (examining the interplay between a country's political deficiencies and IMF's monetary assistance efforts); Emma C. Murphy, Legitimacy and Economic Reform in the Arab World, 3 THE J. N. AFR. STUD. 71 (1998) (providing details on economic liberalization programs in Third World countries).

29. See generally GaLAL AMIN, WhateVER HAPPENED to THE EGYPTIANS? CHANGES IN EGYPTIAN SOCIETY FROM 1950 TO THE PRESENT (2001).

30. See Egypt: Economic and Financial Data, MinisTRY of Planning (Oct. 18, 2011), http://www.mop.gov.eg/MOP_Meta/NSDP.htm (providing updated statistics about Egypt).

31. Egypt, THE WORLD BANK, http://www.worldbank.org/en/country/egypt (last visited Oct. 3, 2012) (providing general up-to-date information about Egypt, including GDP growth rate from 2003 to 2011 ). 


\section{Figure 1: GDP in EGYPT}

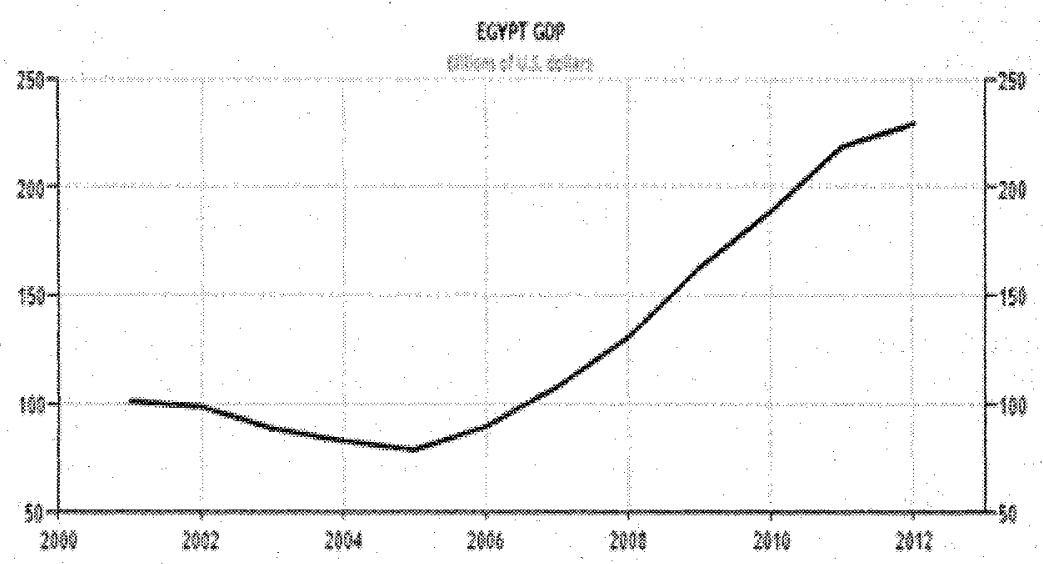

Source: Egypt GDP, TRADING ECONOMICS, available at http://www.

tradingeconomics.com/egypt/gdp (last visited Mar. 27, 2013).

The World Bank's privatization program has also boosted international trade, increased investment flows, and liberalized the economy. In 2007 the growth rate reached about 5 percent due to free trade treaties with European Free Trade Association (EFTA) countries and free trade agreements with Turkey, Morocco, Jordan, Tunisia, and the Common Market for Eastern and Southern Africa (COMESA) countries. ${ }^{32}$

Yet this growth rate was to no avail as a chronic fiscal deficit remained due to high energy and food subsidies and because of the corruption associated with subsidies, particularly in the field of energy. Additionally, high rates of inflation (20.2 percent in 2008 and 10 percent in 2009-2010) harmed the middle and lower classes. ${ }^{33}$ Political instability in Egypt also led to a decline in the number of tourists, resulting in declining tourism revenues and investments. Further, with the revolution in Libya, hundreds of thousands of Egyptians working in Libya returned to their homes in Egypt, which led in turn to a decline in

32. Marek Dabrowski, Egypt: Political Transition vs. Economic Challenges?, 7 CASE NETWORK E-BRIEFS 1, 2 (2011), available at http://www.case-research.eu/upload/ publikacja_plik/34292976_Ebrief_2011_7_Dabrowski.pdf (providing that the growth rate was $5 \%$ ).

33. Monthly Inflation Note, CENTRAL BANK OF EGYPT, http://www.cbe.org.eg/MonetaryPolicy/Inflation-Press-Release_EN.htm (last visited Nov. 19, 2012) (providing inflation rates from 2009 to the present). 
remittances. ${ }^{34}$ Political instability in Yemen also had a negative impact on traffic in the Suez Canal. ${ }^{35}$

\section{Figure 2: GDP growth in Egypt ${ }^{36}$}

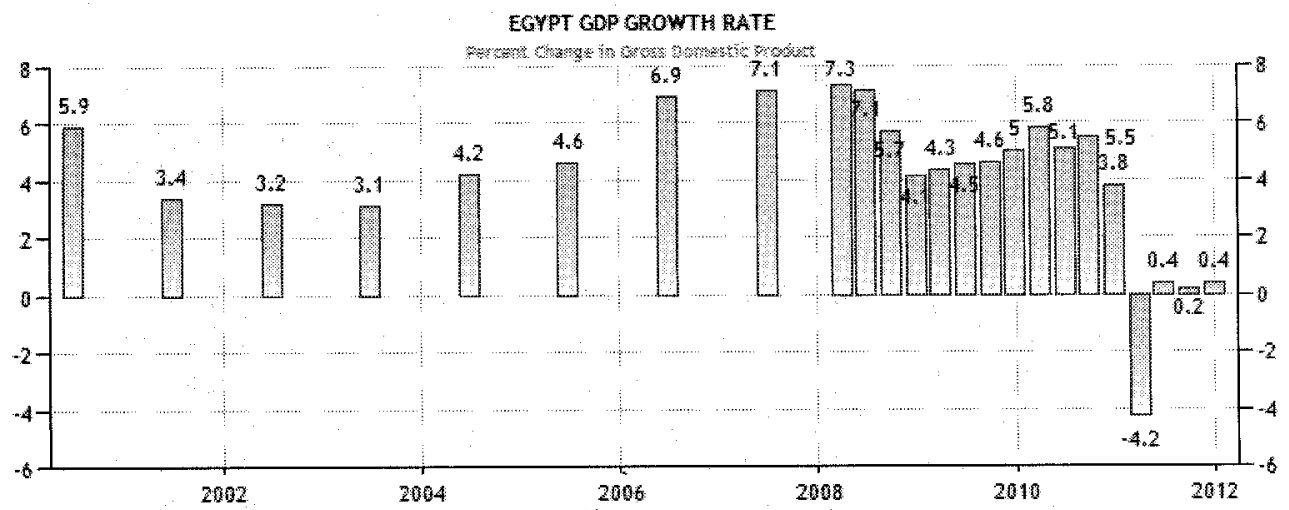

Source: Egypt GDP Growth Rate, TRADING ECONOMICS, auailable at http//www tradingeconomics.com/egypt/gdp-growth (last visited Mar, 27, 2013).

Furthermore, the policies of the ruling military junta and Essam Sharaf's government exacerbated economic and social suffering. The government's unprepared responses to social and factional demands has escalated protests and pushed the people to take to the streets and demand their due. In addition to all this, the situation got worse with increased demands to fight corruption and prosecute leaders of the old system. The business and investment climate has been affected by these events, bringing about an atmosphere of uncertainty about the future.

The growth rate is not expected to exceed 1 percent in the coming years and the fiscal deficit is expected to increase to 11 percent of GDP in 2011-2012.37 Among other negative consequences are high public debt and the decline of international reserves in the Central Bank from

34. See Rocio Sanz, Socio-Economic Profile of Egyptian Migrants Returning From Libya Due to the Crisis; Sample Analysis (August 2011), INTERNATIONAL ORGANIZATION FOR MIGRATION, THE MIGRATION AGENCY, CAIRO, http://egypt.iom.int/Doc/111006_ Profiling_Egyptian_Migrants_FINAL.pdf (last visited Mar. 13, 2013).

35. See Marek Dabrowski, Egypt: Political Transition vs. Economic Challenges?, 7 CASE NETWORK E-BRIEFS 1, 2 (2011), available at http://www.case-research.eu/upload/ publikacja_plik/34292976_Ebrief_2011_7_Dabrowski.pdf (providing that the growth rate was $5 \%$ ).

36. Egypt, supra note 31.

37. Dabrowski, supra note 32 , at 3 . 
$\$ 36.038$ million in 2010 to $\$ 27.243$ million at the end of May 2011.38 Additionally, free trade agreements have contributed to a prevalent negative perception of globalization. Many view these agreements as serving the interests of Western countries and of only a limited group in Egypt. ${ }^{39}$

\section{PRotests}

Although political and economic conditions resulted in the growth of protest movements, it is necessary to point out that Egyptian protests had not yet started with the call for demonstration on January 25, 2011. Egypt has a long history of protest, the most recent wave of which began in 2000.40

The 1977 uprising against Anwar Al-Sadat's economic austerity measures was followed, in 1986 , by the uprising of the Central Security soldiers of the Ministry of the Interior, which was subsequently suppressed by the army. In the 1990 s, the country witnessed a wave of violence led by "Jihadist" movements intending to overthrow the Egyptian regime. This violence was suppressed by the regime, and tens of thousands of people were sent to exceptional or military courts. ${ }^{41}$ In addition, since the Taba bombings in October 2004,42 Egypt has suffered a security problem in the Sinai peninsula, which escalated after the January 25th revolution and ended with the Rafah border attack that killed sixteen militants.

At the turn of the millennium, Egyptian cities witnessed peaceful demonstrations about external issues, first in 2000 against Israeli policies in the Gaza Strip and West Bank, and then in 2002 against the U.S. invasion of Iraq. In 2003, in Cairo, the first coordinated demonstration between the then ruling National Party and the Muslim Brotherhood took place. The two organizations joined forces to hold a huge rally in the Cairo Stadium to condemn American policy in Iraq.

38. Id.

39. See Riad al Khoury, EU and U.S. Free Trade Agreements in the Middle East and North Africa, 8 CARNEGIE PAPERS 1, 22 (2008), available at http://carnegieendowment.org/ files/cmec8_al_khouri_final.pdf (discussing free trade agreements and perceptions of "Western-led globalization").

40. Marie Duboc, Socipolitical Mobolization in Egypt, in SocIal PROTEST AND CIVILIAN REVOlu'tions IN ARAB COUNTRIES 143-45, (Nabil Abdelfattah ed., 2011).

41. Denis J. Sullivan \& Kimberly Jones, Global Security Watch, EGypt: A REFERENCE HANDBOOK 29 (2008).

42. INT'L Crisis Group, Middle E./N. AFR. R. No. 61: EGYPT'S SINAI Question 1 (2007), available at http://www.crisisgroup.org/ /media/Files/Middle\%20East\%20North\% 20Africa/North\%20Africa/Egypt/61_egypts_sinai_question.pdf. 
In the meantime, Egypt witnessed three important developments: two political and the third related to the labor sector, all concerned with informal politics.

\section{A. Kifaya Protest Movement}

The first political development consists of the emergence of the first protest movement called "enough" or the Kifaya movement, which opposed Mubarak's plan for hereditary succession. ${ }^{43}$ The Kifaya movement organized a series of demonstrations against the President and his plan; however, the protests were surrounded by a large number of Central Security soldiers. Nonetheless, Kifaya succeeded in achieving at least two important goals. The first was breaking the psychological barrier of fear, which prevented Egyptians from criticizing the president. Kifaya planted the seeds of a culture of social protest. The second accomplishment was overriding chronic differences and divisions within the Egyptian opposition and thus forming a protest movement. Kifaya was formed as a cross-ideological movement encompassing activists from both the left and right, as well as both Islamists and independents.

However, the movement has not developed certain tools necessary for a successful protest movement, such as internal coherent organization, mobilization strategy, and recruitment means. Kifaya was also faced with obstacles related to the nature of the rentier state and clientelism with millions of people dependent on state jobs. Other obstacles included the divisions within the ranks of the opposition and Kifaya's shortcomings in building long-term political alliances based on the basic tenets of democracy. Kifaya failed to mobilize a large number of people on its political agenda and was unable to impose itself as a political power with a strong and popular base. 44 Thus it remained an elitist movement in the eyes of many.

\section{B. Labor Protest}

Although the Mubarak regime had a tremendous ability to cope with economic challenges and deal with opposition actors, a wave of labor protests erupted, making social and economic demands during the first decade of the twentieth century. ${ }^{45}$ Labor protests were not an

43. See Rabab El-Mahdi, Enough!: Egypt's Quest for Democracy, 42 CoMP. PoL. STUD. 1011, 1012-13 (2009).

44. Duboc, supra note 40 , at 146 .

45. See generally, Mahmoud Abbas, Egyptian Labor Syndicates: A Revolutionary Vision (Cairo: Socialist Studies Center, 1996). 
entirely new phenomenon, but they resulted in part from the Kifaya movement's activities. These protests were independent from the formal political parties, including leftist and nationalist parties such as the Altagmoa party and the Nesserist party. The protests were also independent from the MB.

The state-run Spinning and Weaving Company in Mahalla al-Kubra-established by the well-known economist Talaat Harb (1867-1941) in 1927 and worked by some twenty-two thousand workers-has a long history of struggle against the government. Protests at the Spinning and Weaving Company erupted during the 1930 s and 1940s, during the 1970s and 1980s, and from 2006 to the present. ${ }^{46}$ As noted, Egypt has experienced major social changes since it implemented a free market economy in 1991. While the regime continues to coerce and suppress opposition and civil society, most Egyptians' living standards and economic conditions have deteriorated.

The recent wave of labor protests is due to the intensification of the regime's repression and grip on political and labor activities. In 2007, Egypt witnessed over one thousand protests of various kinds. In a study by the Land Center for Human Rights in July 2007, entitled "Protest in the Face of Savagery," 283 protests were monitored in the first half of 2007 alone, across three economic sectors: the governmental sector, the private sector, and the business sector. During the first half of 2009 there were 432 protests, and another 187 were held in the second half of $2010 .{ }^{47}$ The report mentions many reasons for these protests; aside from low wages and high food prices, the main reason listed is the failure of both the neoliberal reforms and the export-oriented economy prescribed by World Bank and the International Monetary Fund for Egypt in the 1990s. Many Egyptians believe the World Bank program was responsible for the suffering of the greatest number of Egyptians. ${ }^{48}$ Indeed, in 2010-2011, 25.2 percent of the population lived below the poverty line (21.6 percent in 2008-2009 and 16.7 percent in $1999-2000) .{ }^{49}$ In $2008,15.4$ percent of the population was living on less than $\$ 2$ a day. 50

46. Id.at $147-49$.

47. Land Center for Human Rights, Protest in the Face of Savagery (2007); ECONOMIC AND SOCIAL RIGHTS SERIES, http://www.lchr-eg.org/77/77-56.htm (last visited Mar. 13, 2013).

48. Galal Amin, Egypt and Egyptians in Mubarak's Era (1981-2008) (Cairo: Merit, 2009).

49. Central Agency for Mobilization and Statistics, Egypt (الجهاز المركزي للتعبنة والإحصاء), ARAB RePublic of EgYPT, Central Agency For Public Mobilization and Statistics, available at http://www.capmas.gov.eg/pdf/studies/pdf/enf1.pdf (last visited Mar. 4, 2013).

50. Egypt, THE WORLD BANK, http://data.worldbank.org/indicator/SI.POV.2DAY/ countries/EG?display=default (last visited Mar. 4, 2013) (providing general up to date 
Coverage of Egypt by the western media has not focused on these economic factors, but rather on the oppression of civil society and on human rights abuses. ${ }^{51}$ In fact, Egypt has long been an important U.S. ally and a major mediating player in the Arab-Israeli conflict. Thus, United States' interests have often predominated over Egypt's domestic politics.

The widespread fraud in trade union elections in 2006 contributed to the mobilization of workers in demonstrations in 2007. The fraud closed all legitimate means of expression and allowed those who were kept out of the elections to mobilize their fellow workers to protest and establish a network of protesters to provide basic services. ${ }^{52}$ Some field studies have shown that most activists were individuals excluded from participating in the elections. ${ }^{53}$

Privatization, the sale of public company assets, and the early retirement system all threatened the living standards of workers; $; 4$ there has been no new investment in the firms that own the sold assets. This has been compounded by the threat created by the 2003 new labor law. 55

Finally, and most importantly, it must be reiterated that these labor protest movements made nonpolitical demands and remained independent from the traditional political parties-leftist, nationalist, and Islamist. The protests confused the ruling party and surprised the opposition forces, including the Islamists, who did not seem comfortable with nonaffiliated protest movements. ${ }^{56}$ However, from a group theory perspective, this social mobilization and the accompanying demands are in essence political, as the mobilization is a form of applying pressure on decision makers in order to achieve legitimate social and economic goals. However, this kind of protest also lacked organization and leadership.

information about Egypt, including GDP growth rate from 2003 to 2011); Central Agency for Mobilization and Statistics, Egypt, supra note 49.

51. See, for example, the periodic reports of Human Rights Watch. Egypt, HUMAN RIGHTS WATCH, http://www.hrw.org/middle-eastn-africa/egypt (last visited Mar. 13, 2013).

52. Duboc, supra note 40, at 156.

53. Id. at 151 .

54. Id. at 149-51.

55. Id.

56. See Hossam Tammam (تصام حسام), the Sacial Question of the Muslim Brotherhood (المسلون (الإخوان لاى الاجتمية المسلك), ALGHAD.COM, http://alghad.com/index.php/article/ 130212.html (last visited Nov. 19, 2012). 


\section{ElBaradei's Return and the Formation of NAC}

The third political development relates to the return of the Egyptian diplomat and Nobel laureate Mohamed ElBaradei and the formation of the National Assembly for Change (NAC), a group which includes public figures and representatives from the major opposition parties and the MB. This movement started its activities by gathering signatures for seven specific demands. It focused on the electoral process and asked to end the state of emergency. The NAC also wanted to enable the Egyptian judiciary to fully supervise the entire electoral process and wanted to enable civil society organizations-both local and international-to monitor election. It demanded that equal opportunities in the media be provided for all candidates, especially during presidential elections. It called for Egyptians abroad to be able to exercise their right to vote in embassies and consulates. It also wanted to ensure the right for any individual to run in the presidential elections without any arbitrary restrictions, to limit the right to run for the presidency to two terms, and to hold elections by National Identity Number. ${ }^{57}$ NAC activists used all possible means of peaceful demonstrations and strikes. Youth groups within NAC also effectively used social networks to disseminate human rights violations and to rally opponents of the regime to take action in the streets.

Given the intransigence of the regime, the regime's continued refusal to respond to demands and implement reforms, and the blatant fraud that took place in the parliamentary elections of late 2010, public anger grew and the number of strikes and demonstrations increased. ${ }^{58}$ A few days after the fall of Zine El Abidine Ben Ali in Tunisia, following a popular revolution, youth groups in Egypt called for an "Anger Revolution" on Tuesday, January 25, 2011 (Police Day). The youth groups' aim was to denounce regime policies and to ask for genuine reforms. The groups developed their demands to bring down the regime, to prompt the departure of Mubarak, and to encourage the drafting of a new constitution. Media and information technology assisted the youth groups in their efforts. ${ }^{59}$

\footnotetext{
57. The Seven Demands, NAT'L ASSEMBLY FOR CHANGE, http://taghyeer.net/who-we-are/ (last visited Nov. 19, 2012) (providing the seven principle demands of the NAC).

58. See reports by the Land Center for Human Rights. Activity Reports, Social and Economic Series, LAND CENTER FOR HUMAN RIGHTS, (مركز الأرض لحقون الإنسان), http://www.lchr-eg.org/ (last visited Mar. 13, 2013).

59. Youth demands can be found on social media websites. The most important is the "We Are All Khaled Saed" Facebook page, available at http://www.facebook.com/El Shaheeed?ref=ts\&fref=ts (last visited Mar. 13, 2013).
} 


\section{MEDia, INFORMATION TECHNOLOGY, AND PRotest}

Facebook has become a force used by about fifteen million users in the Middle East; Saudi Arabia and Egypt's Facebook community has seen the strongest growth among Arabic users as reported in 2010, as the following table shows. ${ }^{60}$

\section{Figure 3: Top five Facebook communities in the Middle East and North Africa}

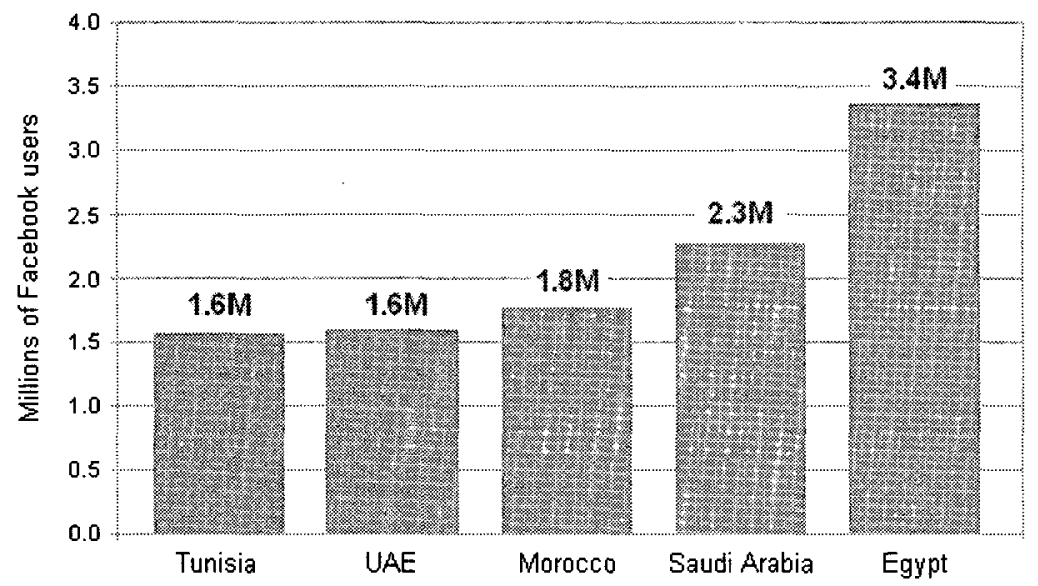

Source: Carrington Malin, 15 Million MENA Facebook Users - Report, SPOT ON PUBLIC RELATIONS, May 24, 2010, http://www.spotonpr.com/ mena-facebook-demographics/ (last visited Mar. 13, 2013).

In fact, youth movements have led Egypt's protests using social media networks to mobilize and ask people to demonstrate. These movements were affected by what happened in Tunisia and became convinced that Tunisia's success in toppling Ben Ali proved that they could overthrow Hosni Mubarak in Egypt. ${ }^{61}$ The most prominent youth movement was the April 6th Movement, which asked Egyptians on Facebook to support the demands of al-Mahalla al-Kubra's workers in their strike on April 6, 2008.62

60. Carrington malin, Spot on Pub. Relations, Middle East \& North Africa FACEBOOK DEMOGRAPHICS 3 (May 2010), available at http://www.spotonpr.com/wpcontent/uploads/2010/05/FacebookMENA_24May10.pdf.

61. Sarah Ben Neffissa, 18 Days of the Egyptian Revolution, in SocIAL ProteST AND Civilian REvolutions in ARAB CounTries 305 (Nabil Abdelfattah ed., 2011).

62. See 6 APRIL YouTh MOVEMENT, http://www.6april.org (last visited Oct. 6, 2012) (official website); see also David Wolman, The Techie Dissidents Who Showed Egyptians How to Organize Online, ATLANTIC, Feb. 3, 2011, available at http://www.theatlantic.com 
Although a revolution requires organization, leadership, funding, and mass appeal, social networking media certainly facilitates publicizing messages rapidly and broadly as well as launching a massive call to action in seconds; however, social networking does not necessarily motivate people to go to the streets and fuel a revolution. In fact, the rise of youth protest movements can be explained by the end of the media monopoly in recent years and by the emergence of independent newspapers, satellite channels, talk shows, and social networking sites on the web. Such means have enabled protesters to disseminate information, post YouTube videos, communicate, and circumvent state control. Satellite channels and talk shows have helped shed light on socioeconomic problems. Newspaper articles by well-known writers, youth blogs, and Facebook pages have all contributed to expose the gravity of the emergency law and the ruling party's policies. ${ }^{63}$

In the recent protest movements, a number of activists used social media tools. They created Facebook pages and groups, Twitter accounts, and personal blogs to mobilize their fellow activists, communicate their message, and ultimately take on street action. Following the death of a young man in Alexandria in June 2010, the Facebook page "We are all Khalid Said" was created to disseminate information about Said's death. The page gradually expanded to contain political debates on the brutality of the regime and the need for reform. ${ }^{64}$ Wael Goniem was one of the administrators of this page. Ghonien was a notable Internet activist during the Egyptian revolution and was on the "Time 100" list of one hundred most influential people of $2011 .{ }^{65}$

ElBaradei was among the figures who took advantage of social media tools to disseminate information and communicate with his supporters. ${ }^{66}$ Omar Afifi, a former Egyptian police officer, was another activist who participated in the revolution using social media tools. Afifi

/technology/archive/2011/02/the-techie-dissidents-who-showed-egyptians-how-to-organizeonline/70734/ (discussing gathering online as a way around laws possibly preventing a gather of more than five people).

63. Sarah Ben Neffissa, Mobilization and Revolutions in Mediterranean Arab Countries, in Social Protest AND Civilian Revolutions IN ARAB CounTRIEs 44-48, (Nabil Abdelfattah ed., 2011); Sarah Ben Neffissa, 18 Days of the Egyptian Revolution, in Social Protest aNd CIVILIAN Revolutions IN ARAB COUNTRIES 311, (Nabil Abdelfattah ed., 2011).

64. Nahed Eltantawy \& Julie B. Wiest, Social Media in the Egyptian Revolution: Reconsidering Resource Mobilization Theory, 5 INT'L J. COMM. 1207, 1213 (2011).

65. Mohamed ElBaradei, Wael Ghonim: Spokesman for a Revolution, TIME, April 21, 2011, available at http://www.time.com/time/specials/packages/article/0,28804,2066367_ 2066369,00.html.

66. Eltantawy \& Wiest, supra note 64 , at 1213 . 
wrote a book in 2008 advising people how to avoid police brutality. ${ }^{67}$ Following the Tunisian revolution, on January 14, 2011, he continued to advise people from the United States via YouTube videos, Facebook, and Twitter, giving advice on topics such as peaceful protest techniques, where protesters should gather, and what they should wear.68

Although the government restricted the Internet and cell phone calls during the early days of protest in an effort to curb the demonstrations, the government's attempts at repression failed as protesters used other ways to communicate and displayed a high degree of flexibility in networking. ${ }^{69}$ Satellite TV shows, especially on Al Jazeera, continued to contribute to mobilization against the regime.

The use of the Internet has had an effective impact on mobilization and protest, yet changes in Egyptian culture have also contributed to mobilization and protest. Some argue that networked society is the important factor in mobilization and protest, and not solely the means of the Internet or phone communications (networked communication). ${ }^{70}$

In addition, a successful revolutionary movement should be able to appeal to groups that do not use the Internet. As in most developing countries, the middle and working classes, retirees, and rural individuals might not have access to the Internet. ${ }^{71}$ In Egypt, young people who use social networking tools were not alone in the revolution, as youth from poor districts, who do not use social networking tools, joined them. The list of martyrs' names has proven this fact, as a large number of the martyrs came from Cairo's slums. ${ }^{72}$

67. Id.

68. Affif's clips are available online. See Omar Afifi (عفيفي عمر) January 14 Tunisian Freedom Day \& Our Date is January 25 (موعنا يناير 25 تونسو حرية عيد يناير 14 عنيفي عمر), YoUTUBE (Jan. 21, 2011), http://www.youtube.com/watch?v=gdJQRz0BtU8\&feature= related; Omar Afifi (عفيفي), How to Protest Peacefully 1 (علي السلمي للتظاهر عامه وإرثنادات عفيفي عمر) المستر), YOUTUBE (Jan. 21, 2011), http://www.youtube.com/watch?v=ujtIdyfjgWU; Omar

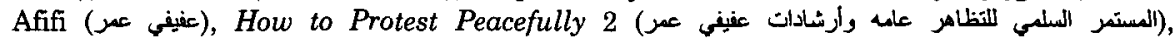
YouTUBE (Jan. 21, 2011), http://www.youtube.com/watch?v=YYheiPStXtY\& feature $=$ related.

69. See Adam Knowlton, Networked Egypt: The Networked Society and the Democratization Movement in Egypt (May 3, 2011) (unpublished student coursework, University of Nebraska-Lincoln), available at http://www.academia.edu/1334173/ Networked_Egypt_-_The_Networked_Society_and_the_Democratization_Movement_in_ Egypt (discussing the failure of Egyptian forces to restrict internet access and the impact of that failure).

70. Id. at 9.

71. Neffissa, supra note 61, at 305-06.

72. Id. at 305. 
Furthermore, among the drawbacks of social media is the lack of security ${ }^{73}$ It can be exploited by those in power, as was the case in Egypt. The authorites monitored protesters' Facebook and Twitter accounts, cut the citizens off from the Internet and cell-phone calls, and ultimately arrested about forty leaders of the April 6th Movement. ${ }^{74}$ The government subsequently used social media for its own purposes, spreading disinformation to weaken the protest movement.

Leadership is crucial here, as some analysts believe that "while the effectiveness of the tool depends on the quality of a movement's leadership, a dependence on social media can actually prevent good leadership from developing."75 In the case of Egypt, youth protesters have not developed a leadership beyond the virtual world, either before or after January 25, 2011.

\section{The TRANSITION PERIOD}

Based on other regime transition cases in different parts of the world, there is a need for agreement among the major political forces on what should be done to achieve the desired political system. In Egypt, the majority of political forces that participated in the revolution have identified democracy as the needed political system, yet there have been major differences among political forces regarding two aspects of democracy. ${ }^{76}$

The first difference concerns the particulars of the desired democratic system, such as the parliamentary structure, the executive structure, the relationship between the executive and the legislature, the electoral system, and party organization. ${ }^{77}$ The second point of difference is how to reach democracy while managing the transition period smoothly. ${ }^{78}$ Many mistakes and mismanagements have been

73. See generally Bruce Etling, Robert Faris \& John Palfrey, Political Change in the Digital Age: The Fragility and Promise of Online Organizing, 30 SAIS REV. 37 (2010) (discussing the use of digital networking to affect political change and the adversities faced in its implementation).

74. Marko Papic \& Sean Noonan, Social Media as a Tool for Protest, STRATFor (Feb. 3, 2011, 9:54 AM GMT), http:/www.stratfor.com/weekly/20110202-social-media-tool-protest \#ixzz22KfBMk00.

75. Marko Papic \& Sean Noonan, Social Media as a Tool for Protest, STRATFor (Feb. 3, 2011), http://www.stratfor.com/weekly/20110202-social-media-tool-protest.

76. See generally, Abdelfattah Mady, What Do We Need From the New Constitution?, ALSHOROUK NEWSPAPER, May 19, 2012, http://www.shorouknews.com/ columns/view.aspx?cdate $=19052012 \& \mathrm{id}=\mathrm{c} 7 \mathrm{~d} 24021-7925-4370-81 \mathrm{cb}-6 \mathrm{f} 8931 \mathrm{a} 7 \mathrm{bf} 4 \mathrm{~b}$.

77. $I d$.

78. See Abdelfattah Mady (عبدالفتاح هاضي), Do Egyptians Need a Corrective Revolution? (هل) يحتاج المصريون إلى ثورة تصحيحية؟), ALJAZEERA (Dec. 2, 2011, 1:41 pm), http://www.aljazeera.net /analysis/pages/2c523b12-4af1-4981-a38c-d8e4d482d6cb. 
committed by Egyptian political forces during the transition, including youth protest movements, political parties groups, and the Supreme Council of the Armed Forces (SCAF) taking the power to govern Egypt after the ousting of Hosni Mubarak. ${ }^{79}$

A common belief during revolutions is that people can do whatever they wish, whenever they wish. ${ }^{80}$ It is true that revolutions urge people to abandon their state of fear and apathy, yet taking this too far may be a threat to the revolution itself because people get used to breaching law and order to assert their rights before a popularly elected government is established. Popular pressure in Egypt has achieved many accomplishments since January 25, 2011, but the priority in the post-revolution period should have been drafting a constitution and building institutions. The elected government and state institutions could then protect liberties and handle socioeconomic issues. ${ }^{81}$

Many youth protest movements have not realized the value in prioritizing the creation of political systems. Some activists have focused on socioeconomic demands, while others have been interested in appearing in the media and writing to the press. The reality is that the activists have not devoted their time and effort to building new political parties or nongovernmental organizations (NGOs). More importantly, the movements have not realized that the transition period should not be long, but it needs a great deal of compatibility and compromise. Youth protests movements have also not realized the gravity of transferring elite disagreements to the general population before reaching a compromise, and that priority should be given to a law-building institution. ${ }^{82}$

The dispersion of youth demands is another mistake. Some activists have not seen any need to focus on democracy now, while others have not understood the seriousness of the politicization of the SCAF. There have also been individuals who think that the revolution must continue

79. See Abdelfattah Mady (عبدالفتاح ماضي), Why Democracy Transformed From a Solution

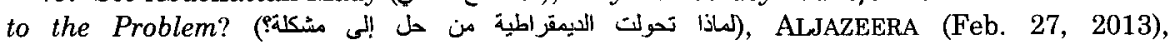
http://www.aljazeera.net/analysis/pages/bleef2ea-d153-4691-97add02a980b91f7?GoogleStatID=24.

80. Abdelfattah Mady (عبدالفتاح ماضي), Risks before the Egyptian Democratic Transition

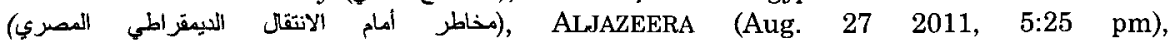
http://www.aljazeera.net/ analysis/pages/5ffa0691-afb0-4dbd-b329-5015b02e3aed.

81. Abdelfattah Mady (عبدالفتاح ماضي), The Presidential Election and the Future of Egypt's Revolution (مصر في الثورة ومسنقبل الرناسة انتخابات), ALJAZEERA (June 22 2012, 2:49 pm), http://www.aljazeera.net/analysis/pages/f54bef32-114f-4048-91ced1125492d7b1? GoogleStatID=1.

82. Abdelfattah Mady (عبدالفتاح ماضي), Do Egyptians Need a Corrective Revolution? ( هلخاح),

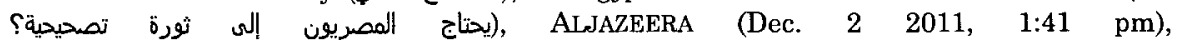
http://www.aljazeera.net/analysis/ pages/2c523b12-4af1-4981-a38c-d8e4d482d6cb. 
until all forms of power are ended or all social and economic demands are achieved. ${ }^{83}$ Another danger is the political division and ideological polarization between existing political currents. After the ousting of Mubarak, some political forces focused on their own interests, overlooking the national priority of institution-building and the rule of law. ${ }^{84}$ There is a perception among the political forces that the gains that have not been obtained will now never be obtained. ${ }^{85}$ The Muslim Brotherhood's support of the constitutional amendments in March 2011 could be understood as a way to obtain the majority in the parliament. ${ }^{86}$

SCAF members have also committed mistakes during the transition period. ${ }^{87}$ They did not realize that the objectives of the revolution were not only to overthrow Mubarak and stop his plan to install his son as a successor. Egyptian generals chose not to do what military leaders did in Brazil, Argentina, South Korea, the Philippines, Tunisia and, other countries where the military supported the democracy movements. The SCAF failed politically in managing the transition when they insisted on making constitutional amendments and a referendum before ensuring wide political agreement on the amendments. The result was that political forces' differences were transferred to the street, which in turn led to political and ideological polarization among people. ${ }^{88}$ The SCAF also failed in establishing internal security and clashed with rebels from August through December 2011. Additionally, the SCAF

83. See generally Abdelfattah Mady (عبدالفتاح ماضی), Non-Traditional, Violent Groups: Black Bloc and Ultras (مجموعات المنف غير الثقلينية.. البلاك بلوك والألتراس نموذج), ALJAZEERA CENTER FOR STUDIES, Feb. 14, 2013, http://studies.aljazeera.net/issues/2013/02/201321493758815121. htm.

84. Mady, supra note 79.

85. Abdelfattah Mady (عبدالفتاح ماضي), Risks Before the Egyptian Democratic Transition (مخاطر أمام الانتقال (ALJAZEERA (Aug. 27 2011, 5:25 pm), http://www.aljazeera.net/ analysis/pages/5ffa0691-afb0-4dbd-b329-5015b02e3aed.

86. Id.

87. For more detail on the SCAF and the democratization in Egypt, see YEZID SAYIGH, Carnegie Middle East Center, Above the State: The OfFicers' RePublic IN Egypt (2012), available at http://carnegie-mec.org/publications/?fa=48972; INT'L CRISIS GROUP, MIDDLE E./N. AFRICA R. No. 121, LOST IN TRANSITION: THE WORLD ACCORDING TO EGYPT'S SCAF (2012), available at http://www.crisisgroup.org/ /media/Files/Middle\%20East\%20 North\%20Africa/North\%20Africa/Egypt/121-lost-in-transition-the-world-according-toegypts-scaf.pdf.

88. See Abdelfattah Mady (عبدالفتاح ماضي), A Message to Field Marshal Tantawi: It's a Matter of Time (وقت مسالة إنها :انمشير إلى رساله) SHOROUKNEWS.COM (Feb. 5, 2012, 9:10 am), http://www.shorouknews.com/columns/view.aspx?cdate=05022012\&id=b72ba22f-b4754070-8976-c2b08b7b19c4. See also Abdelfattah Mady (عبدالفتاح ماضس), Compatibility first and not the constitution or elections (التوانف اولا وليس الدستر او الانتخابات), ALJAZEERA.NET, June 23, 2011, http://www.aljazeera.net/analysis/pages/ad6dfdfa-a21c-437b-8745-8fdbcoff5ab9. 
chose to have a weak Cabinet with no real power, which failed to deal with social and economic demands. ${ }^{89}$

\section{THE FUTURE OF DEMOCRATIZATION IN EGYPT}

In the Egyptian transition period, there has been a need for a national coalition or alliance between the different political parties, as well as protest groups to manage the transition; such components lay the foundation for a successful democratic government. This is referred to as a "democratic, historical bloc."90 This bloc is considered historical because it faces a historical challenge after the Egyptian revolution: building a new political system. It is democratic because democracy shall be the common priority for the parties involved. Political differences and ideological contradictions should not prevent alliances among these parties; they need to work together to achieve a common goal that paves the way toward proper political and ideological competition, based upon true democratic rules. Mohamed Morsi, the first elected president after the revolution, has a historic chance to form and lead this alliance.

The development of such a historical bloc has at least two prerequisites. First, the conviction that the common ground and priority in such a historical moment is for democracy as a system of governance. Second, the exercise of democracy from within those powers and groups. To satisfy the first prerequisite, the parties of the bloc should remove mutual accusations from their political discourse and abandon any attempts to dig into past files or to anticipate future intentions of different political groups. The parties should understand that such a historical moment requires overcoming past discords for achieving a historical goal that will benefit everyone. There must be a conclusive and final declaration by the bloc that the priority is to move together towards democracy; this is what happened in Poland, ${ }^{91}$ the Philippines, ${ }^{92}$ and Ukraine. In Ukraine, the opposition was successful when the groups involved put aside their past disagreements and

89. Id.

90. See Ali Khalifa Alk-uwari (على خليفة الكراري) \& Abdelfattah Mady (عبالنتاح ماضي), The Concept of Historical, Democratic Bloc, in TOWARDS A HISTORICAL, DEMOCRATIC BLOCK IN THE ARAB COUNTRIES 37-64 (نحو كلة تاريخية نيمتراطية في البلان العربية) (Ali Khalifa Alkuwari \& Abdelfattah Mady eds., 2010).

91. See Gerardo L. Munck \& Carol Skalnik Leff, Modes of Transition and Democratization: South America and Eastern Europe in Comparative Perspective, in TRANSITIONS TO DEMOCRACY 193, 201-03 (Lisa Anderson ed., 1999).

92. See Richard Snyder, Paths out of Sultanistic Regimes: Combining Structural and Voluntarist Perspectives, in SUlTaNistic Regimes 49, 75-76 (H.E. Chehabi \& Juan J. Linz eds., 1998). 
created a coalition in 2004 . The coalition was based on a joint program against the communist president and it was led by a noncorrupt figure. ${ }^{93}$

This approach has been followed by many democratic transitions around the world. In India and Malaysia, opposition groups reached an agreement and established a common ground of understanding. Finding this common ground led to democracy with all of its principles, rules, and institutions. India's Congress Party and The United Malays National Organization represent success stories in which common ground was established. In South Africa, the Congress Party led the struggle for integrating the black majority into society by focusing on democratic representative mechanisms and human rights and liberties.

Furthermore, the different political powers constituting the bloc in Egypt should work on resolving tensions, which have resulted from differing understandings of democracy. Disagreements needing special attention include the relationship between Islamists and democracy; the issues of social justice, development, and poverty; and finally, the means to protect minorities. It can be viewed that dealing with the problematic relationship between Islamic movements and other movements represents an important dimension of democratizing Egypt.

The second prerequisite (exercising democracy from within the bloc and between the powers constituting the bloc) is crucial in light of the presence of many despotic practices within some of the groups. To achieve such a goal, minimal democratic standards-such as rule of law, transparency, alternation of power, tolerance, openness, and self-criticism-must be adopted by those groups. There should be a complete revision of documents, agendas, and reform projects designed to eliminate any undemocratic principles. Finally, democratic leaders should value the country's interests over any personal or sectarian considerations.

93. Taras Kuzio, Ukraine's Orange Revolution: The Opposition's Road to Success, 16 J. DEMOCRACY 117, 121 (2005). 
